L. Matthew Hojo, Jr. James Reid Horney

Charles $O$. Jones

Warren W. Kane

John E. Kern

Allan Kornberg

Avery Leiserson

Michael H. Levin

John A. Limpert

Jennifer P. Marks

David R. Mayhew

Roy D. Morey

Patrick Mulloy

Candice J. Nelson

Ned A. Ostenso

Geneva Overholser

Leonard F. Parkinson

Nelson W. Polsby

C. Herman Pritchett

Dale D. Pullen

Austin Ranney

J. Thomas Ratchford

James P. Rausch

Margaret R. Richardson

David W. Rohde

Barbara B. Rosenfeld

Alan Rosenthal

Catherine E. Rudder

Barry Rundquist

Paul S. Rundquist

Allen Schick

Mark L. Schneider

Stefan von Senger

Patricia Schlueter

Barbara Sinclair

Charles Stewart III

Grady W. Smithey, Jr.

Floyd E. Stoner

Thomas Vocino

Charls E. Walker

Gene N. Washburn

Richard D. Warden

Barbara C. Weber

Bonnie S. Whyte

Aaron Wildavsky

Eddie N. Williams

Raymond $E$. Wolfinger

William Zaferos

Norbert Y. Zucker

\section{Call For Papers: 1990 Annual Meeting}

\section{Policies and Deadlines}

Paper proposals and offers to appear as discussants or panel chairpersons must be submitted as early as possible. The deadline for receipt of submissions is December 1, 1989. Proposals for whole panels are welcome, but persons with suggestions for panels should get their requests in early.

Please write directly to the appropriate section Program Committee andor Organized Section chairperson(s) listed below. More general inquiries of suggestions may be addressed to:

Jane Mansbridge, Center for Urban Affairs and Policy Research, Northwestern University, 2040 Sheridan Road, Evanston, Illinois 60201; (312) 491-8726 (Program Chair).

Ann Peyser or Sheila Langford, APSA, 1527 New Hampshire Avenue, NW, Washington, DC 20036; (202) 483-2512.

Prospective participants should be aware of two APSA Council policies:

(1) Acceptance of a proposal by the Program Committee obligates you to preregister (with appropriate fee) prior to june 1, 1990. If you fail to preregister, you will not be listed in the full program.

(2) Participants may appear on two (but no more than two) panels in any capacity-chairing a panel, acting as discussant or presenting a paper. This rule applies to APSA Program Committee panels, APSA Organized Section Panels, and Unaffiliated Group panels.

\section{Coordination of Program Committee and Organized Section Panels}

You are encouraged to submit paper proposals to Program Committee Sections and the corresponding Organized Section. If you apply to several Program Committee Sections, or apply to Program Committee Sections and Organized Section Panels, please inform each section chairperson that yours is a multiple application. Also, in that case, please notify the other section chairpersons as soon as you have accepted an invitation for participation in another section. 


\section{Program Committee Sections}

Section leaders of the 1990 Program Committee will announce their proposed programs below:

Section I. Political Thought and Philosophy: Historical Approaches. George Kateb, Department of Politics, Princeton University, Princeton, NJ 08544; (609) 452-4860.

This section should tend to the interpretation and illumination of the great and the good works of political theory. To see the life in, or to give new life to, worthwhile books and fragments is the aim. Every perspective is welcome; so is attention to every historical period.

If there is any single subject that is particularly desirable, it is the theoretical study of democracy, ancient and modern-including the theme of the relation between ancient and modern conceptions of democracy.

Democracy is not the only topic that is welcome. Other possible topics are: the need for global or planetary political theory; the possible exhaustion of the ideals of socialism and socio-economic equality; the possible obsolescence of the single society as the frame for political theory; the validity of the idea of the social contract; the validity of the idea of plural moralities; the apparent spread of Nietzsche's influence; the complexities involved in the defense of various kinds of freedom. This list is hardly exhaustive, and it is meant not so much to guide as to suggest lightly.

Metatheoretical proposals are also welcome.

Section 2. Normative Political Theory. James S. Fishkin, Department of Government, Burdine Hall 536, University of Texas at Austin, Austin, TX 78712-1087; (512) $47 \mid-5121$.

The focus will be on broad and ambitious theories dealing with the first issues of political philosophy. These issues can be divided into three broad categories: First, foundational issues which arise from theories of consent, social contract, meta- ethics, rational choice, and the use of hypothetical thought experiments. Second, substantive principles which provide the basis for policy prescription, such as justice, equality, exploitation, liberty and utilitarianism. Third, procedural principles which focus on the design of political institutions, such as democracy, representation, and constitutionalism. The full range of contemporary methodological and ideological approaches will be considered.

Section 3: Formal Political Theory. Thomas Schwartz, Department of Political Science, UCLA, Los Angeles, CA 90024; (213) 825-1972.

Formal political theory has become much more than the interpretation and application of certain ideas, methods, and findings imported from economics. Political scientists have made fundamental technical contributions to social-choice theory, game and bargaining theory, and the spatial theory of voting, and I hope that some of these contributions will be on display in several panels. Not that applied research is unwelcome. On the contrary, I expect the majority of panels in this section to show how formal theory provides tools for the analysis of substantive topics involving strategy, information, institutional design, conflict and cooperation, and any number of other matters, and I hope to arrange some joint panels with other sections.

l especially welcome papers and proposals for panels and roundtables on the design of representative systems, the old and the new institutionalism, the experimental testing of formal models, the ways in which formal theory overlaps and complements political philosophy and political psychology, the compass of classical conceptions of rational behavior, and the ways in which the theorems produced at the core of formal political theory can guide empirical research.

Section 4: Methodology. Nathaniel Beck, Department of Political Science, University of California, San Diego, La Jolla, CA 92093; (619) 534-4296; [BIT-NET beck@ ucsd] and Gary King, Department of 
Government, Harvard University, Cambridge, MA 02138; (617) 495-2027. [BITNET gmk@harvunxw]; FAX (617) 495. 0438.

Panels in this section will be of two types. The first will either apply new methods to existing political science problems or show the utility of existing methods in application to new political science problems; the second will assess the state of methodology in various substantive subfields and deal with more general epistemological issues.

While some of the papers in the first type of panels will report on analyzes of familiar methodological topics (measurement, estimation, inference, cross-sections, panels, time series, selection bias, graphics, simulation, artificial intelligence, data collection, and survey research methods), we especially encourage papers that either design new methods to deal with interesting political science problems or use more standard methods in a new way to take advantage of the political features of a problem. Papers which tackle important substantive issues will be given priority. We also welcome papers that describe the state of the art in some well-defined methodological area (providing the link to important political science issues is made clear).

The second type of panel will deal with broader questions about the role of methodology in the various fields. Possible questions include: should there be a single political methodology? why do some fields of political science seem more methodologically advanced than others? how could we improve the relationship between political theory and empirical methodology? what is (or should be) the relationship between formal theory and empirical methodology? what are (or should be) the relationships between political methodology and the methodological fields in other disciplines? what methodological problems are distinctive to political science? how should the emerging field of political methodology be defined?

While most of the panels will deal with statistical methodology, panel and paper proposals on non-standard and/or nonquantitative methodology are also welcome.
Section 5. Legislative Processes and Politics. D. Roderick Kiewiet, Division of Humanities and Social Sciences, California Institute of Technology, Pasadena, CA 91125; (818) 356-4032.

The past several years have witnessed important advances in the study of legislatures. Most notable have been the many influential analyses of major institutional features, such as voting rules, amendment procedures, and party and committee structures. More than in most areas of political science, the leading theoretical models have received empirical scrutiny, and the empirical work has in turn led to new developments in theory. Proposals for papers that further contribute to the productive interchange between the theoretical and empirical enterprises will be especially welcome. I would also like to solicit papers that examine the workings of legislatures other than the U.S. Congress, including parliamentary bodies, state legislatures, and legislative bodies in nondemocratic regimes. Please send me any suggestions you might have for panels and/or roundtables on legislative processes in noncongressional settings.

Section 6. Executive Politics. Jeffrey $K$. Tulis, Department of Government, Burdine Hall, 536, University of Texas at Austin, Austin, TX 78712; (512) 47I-5121.

The panels on Executive Politics will attempt to advance three objectives: 1) we will probe the convention's general theme, "democratization;" 2) we will encourage research that crosses disciplinary boundaries and involves scholars from diverse subfields; 3) we will try to represent the on-going research interests of presidency scholars.

In addition to a theme panel on "Executive Power and Democratization," interdisciplinary panels might focus upon such topics as: executive power in political theory; anthropological or cultural approaches to presidential politics; executives in international relations; and, perhaps, a panel on Gorbachev.

A number of panels will be closely coordinated with the presidency research organized section. I welcome proposals for papers and panels on any aspect of execu- 
tive politics broadly defined (or redefined). We expect to receive several proposals on perennial topics such as: presidential communication; various constitutional themes; White House organization; presidential character; reinterpretations of one or more presidential eras; new studies of executive-legislative relations; comparisons of presidents and prime ministers. But again, proposals on any aspect of executive politics are encouraged.

Section 7. Political Behavior. Larry $M$. Bartels, Department of Political Science, University of Rochester, Rochester, NY 14627; (716) 275-7840; and Shanto lyengar, Department of Political Science, UCLA, Los Angeles, CA 90024; (213) 8255536.

The newly broadened Political Behavior Section welcomes proposals for papers or panels on electoral behavior, public opinion and socialization, and political psychology. In order to minimize overlap with other sections we will give priority to proposals for individual-level rather than institutional or historical analyses, and to empirical rather than solely theoretical or methodological contributions.

We expect panels to form around several of the following topics: attitude formation, political persuasion and propaganda, election campaigns, personality vs, situational influences on political behavior, cognitive structures, information-processing and ideology, the political impact of mass media, participation, partisanship, candidate evaluation and voting behavior. Additional ideas are, of course, also welcome.

We are especially interested in proposals addressing the connections between individual political behavior and "democratization," and in panels that intersect current research in social psychology and political behavior. These might include analyses of socialization and electoral behavior in new democracies, psychological analyses. of choice and decisionmaking, or more general evaluations of the behavioral underpinnings of normative democratic theory.

Section 8. Political Organizations. Bernard Grofman, School of Social Sciences,
University of California, Irvine, Irvine, CA 92717; (714) 856-6394; and Byron Shafer, Department of Politics, Nuffield College, Oxford OXI INF, United Kingdom; (0865) 278509.

This section will include a variety of organizational forums that link mass publics with elite-not only political parties and interest groups, but also social movements and the media.

We are interested in investigating - even collecting-substantively innovative approaches to political organizations. To that end, a special focus of the panels in our section will be political parties, interest groups, social movements and the media in comparative perspective. This implies comparisons across countries, of course, where the American case is frequently marginalized or overlooked. But it also encourages comparisons across historical periods or across organizational types. In the same fashion, we are particularly interested in proposals for panels which integrate topics often considered separately, such as parties and interest groups, or parties and social movements-topics which have the added virtue of almost requiring comparisons across organizational types or historical periods.

As the preceding implies, we hope to be responsive to proposals for panels and not only for papers. One of us, for example, is interested in the mechanisms for intragenerational transmission of partisan identification, in looking inside the black box; the other is interested in the utility of the oldfashioned notion of party factions and their evolution, in looking at parties as 'covers' for factional activity - though these are offered as examples, not requests. Finally, in line with the overall theme of democratization, we hope to offer several panels on aspects of that theme especially relevant to the section, as perhaps with 'Michel's Iron Law of Oligarchy-Contemporary Evidence' or 'Structural Democratization in American Politics-Movement and Impact.'

Section 9. Public Law and Judicial Politics. Gregory A. Caldeira, Department of Political Science, Ohio State University 223 Derby Hall, Columbus, $\mathrm{OH} 43210$; 
(6/4) $272-4476$ or $292-2880$ (messages), [BIT-NET: TS6532@OHSTMVS].

I welcome proposals for panels and papers from all of the competing approaches we usually group under the broad umbrella of "public law and judicial politics." The theme for this year's program is "democratization," so I am eager to have proposals on the roles of courts in democracies and particularly in the democratizing societies. This might, for example, lend to panels and papers on familiar topics (e.g., the tensions between judicial review and democratic politics in the United States) or on the less familiar (e.g., the influence of constitutional courts in the new democracies of Southern Europe).

The ultimate set of panels will, of course, reflect the usual diversity of our intellectual concerns as shown in previous programs. Proposals might deal with such topics or issues as administrative law and politics, interest groups and courts, state and local courts, courts and policy innovation, relationships between courts and the public, connections between courts and legislatures and executives, comparative law and courts, the changing balance of power in the federal courts during the Bush presidency, uses of the Supreme Court Data Base, and changes over time in judicial policies or behavior.

Finally, I solicit your suggestions for panels and ideas for roundtables.

Section 10. Constitutional Law and Jurisprudence. Sanford Levinson, University of Texas Law School, 727 East 26th Street, Austin, TX 78705; (512) $471-3273$ or 471 . 5151.

There has been a recent spate of writings, by both lawyers and political scientists, on constitutional theory. Much of this literature comes under the broad rubric "constitutional interpretation," and I would certainly expect some proposals in this broad area. I hope that some papers will be comparative rather than focus exclusively on the U.S. Constitution.

In addition to papers on "traditional" jurisprudence, I would especially welcome proposals regarding the interplay between the new feminist jurisprudence and constitutional law and on the contemporary de- bate between "liberals" and "republicans."

Might some classic book serve as the focus of a "retrospective" or "reconsideration?" One candidate that comes to mind is Robert McCloskey's The American Supreme Court (1962).

Finally, in light of the 1990 program's general theme of "Democratization," I would certainly like at least one panel to focus on the linkage between constitutionalism, whether in the United States or in other countries, and democracy. Obvious topics include voting rights, political accountability and separation of powers, and constitutional limitations on majoritarian preferences. (I include in this latter a burgeoning interest in the ability of the state to place conditions on the granting of its largesse.) I would also suggest looking at the 22nd Amendment (having discovered in a trip to China that the Amendment can provoke extremely rich and interesting debate).

No one should feel confined by these suggestions. All proposals are welcome, from any perspective.

Section II. Public Administration. Martha Derthick, Woodrow Wilson Department of Government and Foreign Affairs, University of Virginia, Charlottsville, VA 22901; (804) 924-3192.

Papers that relate public administration to its setting in particular regimes or regime types will be especially welcome this year. In what ways and to what extent does the institutional or cultural context affect the conduct of public bureaucracies? To what extent does public administration exhibit common traits independent of that context? This suggests a preference for analysis that is comparative-as among different nations, or different subnational governments in a federal system, or the different levels of government in federal systems. Panels that hold promise of such comparison, whether through juxtaposing papers or incorporating papers that are themselves comparative, will be encouraged. This emphasis is not meant to be exclusive, however.

Section 12. Urban Politics, State Politics, 
and Federalism. Martin Shefter, Department of Government, Cornell University, Ithaca, New York 14853; (607) 255-6767.

Proposals are invited for panels, roundtables, and individual papers dealing with all aspects of subnational politics. Because responsibility for panels is being shared this year with the organized sections, proposals falling within the fields of federalism, American urban politics, and American state politics may be submitted either directly to me or to the chair of the appropriate section. Proposals that do not fall squarely within one of these subfields should be submitted to me. I also encourage scholars in the fields of American national politics, comparative politics, and international political economy to submit proposals dealing with the impact of urban or regional developments upon national or international affairs.

Proposals for panels should include as much information as possible, including the authors and titles of prospective papers. Proposals for papers should if possible include an abstract.

Section 13. Public Policy. Deborah A. Stone, Brandeis University, Heller School, Waltham, MA 02254: (617) 736-3838.

Contributions in any area broadly defined as policy are welcome. I seek creative juxtaposition of papers into panels that explore new ways of studying policymaking or analyzing substantive policy area. My hope is that panels will emphasize what is generalizable and contribute to theory-building.

Individuals are invited to submit paper proposals and suggest panels dealing with the following themes: (1) definition of problems and agenda-setting; (2) impact of institutions, political processes, culture and norms, global political economy on policy: (3) impact of public choices on political institutions, processes, culture, etc.; (4) methodological innovations and controversies in studying policy making or evaluating policies. I would like to see papers dealing with comparative and crossnational topics integrated into these panels, rather than walled off in separate comparative panels.

in celebration of the first woman presi- dent of APSA, l especially welcome contributions that explore how using gender as an analytic category can give new insights into the processes of problem definition, selection and design of policy instruments, implementation, and evaluation.

Section 14. Politics and Economics. Margaret Levi, Department of Political Science, DO-30, University of Washington, Seattle, WA 98195.

There are at least two meanings to the term "political economy," and I hope to solicit panels that address both meanings. The first is the relationship between political and economic variables. Papers on the political business cycle, union influence and unionization, and the relationship between capitalism and democracy are among possible panel topics.

The second definition of political economy is the application of economic theories, both Marxist and neo-classical, to political phenomena. The most important current issues for this approach are the role of institutions, the sources of preferences, the influence of norms, and the micro-foundations of democracy.

Section 15. Race, Gender and Ethnicity. Jennifer Hochschild, Politics Department. Princeton University, Princeton, NJ 08544; (609) 452-5634.

I envision three kinds of panels for this section. The first would focus directly on issues unique to, or especially important to, a particular group, whether it be women, African Americans, Latinos, Asians, or another ethnic group. Examples might include panels on the politics of rape or comparable worth; the politics of black mayors or housing desegregation; the politics of bilingual education; the politics of Asian immigration, and so on.

A second set of panels would focus on interactions among gender, race, and ethnicity. Examples might include a comparison of the political and economic difficulties faced by black men and black women; or the political environment of Puerto Rican women compared with Chicana women; or the relations between middle class, mostly white women and working class, disportionately black or Latino 
women within the feminist movement.

A third set of panels would focus on the analytic and normative issues involved in the concepts of "gender," "race," and "ethnicity." Why should, or shouldn't, we think in terms of gender rather than sex? Are the postmodernists correct in arguing that it makes no sense to talk in abstract terms of race or gender-that one must always specify a concrete context to say anything illuminating? If race is a socially constructed category, what are the implications of drawing boundaries one place rather than another? Is discrimination against ethnic groups similar to discrimination against blacks?

These are only suggestions, of course, and no paper or panel has to fit into any single focus. I welcome suggestions for whole panels as well as for roundtables, "meet the author" sessions, "three generations of scholars look at X problem" sessions, and other creative ideas as well as for single papers. I especially welcome suggestions for graduate student papers, discussants, or panel chairs.

Section 16. History and Political Science. Amy Bridges, University of California, San Diego, Department of Political Science Q-060, La Jolla, CA 92093; (619) 534-4909.

In the last several years political scientists from a broad array of subfields have taken an interest in historical issues and problems. For some, historical studies expand the number of cases (say, congressional elections or fiscal crises) of phenomena of interest. For others long-standing historical puzzles are appropriate foils for demonstrating the explanatory power of particular theoretical approaches. Still others work at re-telling familiar histories to offer new evidence, themes, or interpretations, or to find the antecedents of current institutional arrangements or political dilemmas.

This section is open to papers and panels reflecting the diversity of historical inquiry in the discipline. Among the themes of interest are reappraisal of Britain as the model for industrial and political development, the fiftieth anniversary of Arthur Schlesinger's "City in American History," antecedents to contemporary democratizations, history of particular institutions (e.g., Congress), patterns in the development of party systems or political coalitions, and the logic of historical analysis.

Section 17. Comparative Politics of Developing Areas. Ruth Berins Collier, Institute of International Studies, Moses 215 , University of California at Berkeley, Berekeley, CA 94720.

Of particular interest in this section will be panels that are well integrated so that the separate papers provide the basis for an explicitly comparative discussion of the different cases and regions presented. A variety of topics are welcome, though I would be particularly interested in the following themes, and in any panels that address the 1990 program theme of democratization.

1. Getting the State Back Out? The recent effort to refocus scholarly attention on the role of the state must be supplemented with attention to a tendency toward the erosion of the scope and importance of state power. This erosion includes important initiatives to privatize state enterprises; contraction of the resource base that supports state economic and social programs; the rapid growth of the informal, non-state-regulated sector of the economy; and, especially in Latin America, the rapid expansion of a key component of the informal sector-the drug trade-in full defiance of the political and legal authority of the state. The causes of this potential retreat of the state are many and varied: a new resurgence of laissez-faire thought, identified in part with Reaganism and Thatcherism; the consequent reorientation of development models, promoted especially by USAID and the World Bank, which emphasize the key role of the private sector, the inefficiencies of the state sector, and the disadvantages of the distortions it produces; and the LDC debt crisis and associated austerity policies, promoted by IMF conditionality, which encourage the contraction of the state. Balanced against these forces are those that support a more interventionist state. For instance, although the successful 
economic model of the Asian NICs has been invoked in connection with the advocacy of the advantages of market forces, this model may also underline the crucial role of a state which is strong, autonomous, and developmental or dirigisteone that is basically market enhancing, but that also in some aspects can be market distorting. This model may further point to the importance of the state in attending to basic distributional problems and the development of human resources. In light of these currents and forces, I invite panels and papers that address the question of the changing role of the state in the Third World. What, so far, has been the commitment to and experience with reducing the size of the state sector? What are the different ways this has been approached? What explains differences in this regard, and what are the economic and political consequences? How have pressures for the contraction of the state been balanced with the logic of the developmental state? How do we conceptualize state autonomy or strength, and with what political arrangements is the developmental state consistent?

2. National Political Regimes and the Changing International Economy. In the last decades, the world has witnessed a dramatic growth in international trade, combined with a reorganization of capital and production on a global scale. Third world countries have been affected by this change, as many have sought to become more integrated into the international economy, restructuring their national economies to be more competitive. Policies of export promotion have focused on both the national industrial sector and MNCs in export production zones. The important political question to ask with respect to these changing economic policies concerns their implications for the distribution of material benefits and pay-offs, for the viability of existing class and political coalitions, for potential alternative coalitions, and for consequent pressures for regime change. How are the political resources of different groups and sectors affected, and what is occurring with respect to state-capital, state-labor, and laborcapital relations? How are these relationships affected by and how, in turn, do they affect different types of political regimes? An interesting theme that arises here is the complex relationship between economic liberalization and political democratization.

Section 18. Comparative Politics of Advanced Industrial Societies. Peter Hall,

Center for European Studies, Harvard University, Busch Hall, 27 Kirkland Street, Cambridge, MA 02138; (617) 495-4303; FAX (617) 495-8509; and Germaine A. Hoston, Department of Political Science, The Johns Hopkins University, Baltimore, MD 21218; office: (301) 338-7531/7540, home: (301) 243-5983; FAX (301) 467-4033.

We welcome innovative proposals for papers and panels that reflect the full range of quantitative and qualitative approaches to comparative politics and interpret the term "advanced" industrialized societies broadly to include the experiences of Japan, Asian NICs, the Soviet Union, and the United States as well as Western Europe. Proposals that are genuinely comparative across nations, regions, or time are strongly encouraged.

In keeping with the theme of the 1990 meetings, we are especially interested in receiving proposals that assess the development and functioning of democracy in the industrialized world, for instance, by reconsidering the linkages between elites and society or the treatment of minorities. In 1990, it would also be appropriate to explore the central political developments of the 1980s, such as religious resurgence and the revival of neo-conservatism, or to reassess developments considered important in light of the experience of the 1980s, such as the growing power of the executive and the expanded role of the state. Some panelists might also wish to reevaluate traditional theories about the development or functioning of democracy from the longer-term perspective of the past century. However, proposals on all aspects of the comparative politics of industrialized societies are welcome.

All proposals should include a brief synopsis of the paper to be presented, and, where possible, proposals for panels 
should leave room for an additional paper to be added from among those submitted individually to the section. All proposals should be sent to both co-chairs; and we encourage the early submission of proposals.

Section 19. Domestic Politics and Foreign Policies of Communist Regimes. Vivienne Shue, Department of Government, Cornell University, Ithaca, NY 14853; (607) 255-3856.

As the processes of "reform," "restructuring," and "opening" continue uncertainly lurching forward in so many widely divergent quarters of the socialist world, we are challenged to reexamine nearly all the categories for analysis and understanding that we have conventionally deployed in our studies of these polities, their structural foundations and their systemic discontents. The reexamination required spans both units of state and of society and it stretches our attention from the fine points of economic organization under market socialism to the fine arts and other modes of individual and cultural expression. The apparent political roles and potential of such old elements of state power as the police, the military, the official media, the formally sanctioned "mass" organizations, planners, bureaucrats, and even the party itself all appear to be in flux. Similarly, the potential political roles and agendas of such elements of society as industrial workers and managers, farmers and artisans, national minorities, the church and the faithful, the intelligentsia and youth, all are either shifting or in doubt.

Panels that attempt or at least pursue a reconceptualization of the forces at play through the processes of reform will, therefore, be most welcome this year. Cross-country comparisons will be encouraged; but panels and roundtables with a single-country focus will also be included. Particularly welcome will be proposals that: (a) attempt a retrospective rethinking of pre-reform political dynamics and/or political ideology in light of present-day prospects and dilemmas; (b) include consideration of religion or popular culture in examining the politics of reform; (c) ad- dress the evolving repertoires of popular protest and dissent under reform socialism; (d) examine the linkages between domestic reform developments and world economic and political affairs, especially recent changes in superpower relations and in second world - third world political alignments; or (e) reflect upon new research opportunities and new methodological problems confronting students of socialist systems in the era of reform.

Section 20. International Collaboration. Michael W. Doyle, Department of Politics, Princeton University, Princeton, NJ 08544; (609) 452-4760.

1 hope to receive suggestions for panels and papers that explore a wide range of questions associated with international collaboration. For example, how might theories of international law and organization relate to the more general theories of cooperation and regime building? Or, what distinguishes coercive from noncoercive collaboration: how do cooperation, persuasion, and peace differ from hegemony and empire? What explains when international collaboration succeeds? What types of collaboration are chosen by what kinds of states, or which elites, in what circumstances? Why have the prospects for significant advances in regional integration in Europe ("1992") improved? I look forward to panels that explore current advances in theory as well as those that present challenging case studies, both histori$\mathrm{cal}$ and contemporary.

In keeping with the 1990 Convention's general theme of democratization, I would particularly welcome suggestions that explore democratic sources of international peace and collaboration and international sources of democratic governance. But 1 also hope to receive suggestions from a variety of different viewpoints that seek to develop new ways of conceiving of the significance of international collaboration across cultures and societies.

Please send a brief written summary of the paper or panel you propose or a statement of the topic or topics for which you would like to serve as a discussant.

Section 21. International Conflict. 
Deborah Larson, Department of Political Science, UCLA, 405 Hilgard Avenue, Los Angeles, CA 90024; (213) 206-5286.

International conflict may be viewed as a bargaining process in which the parties' ability to achieve goals depends on the choices of others. Policymakers therefore decide based on how they expect others to behave. Because of the intermingling of competition and cooperation created by the actors' interdependence, strategic interaction poses difficult problems for such established theoretical perspectives such as Structural Realism, Marxism, or Liberalism. If conflict is a bargaining process, however, useful hypotheses and insights can be gained from various disciplines and levels of analysis, including parent-child relationships, labor negotiations, corruption in city governments, piracy, and crime.

Panels on conflict and cooperation might focus on deterrence, crisis management, crisis prevention, coercion, negotiation, and conflict resolution. More specific panel topics might include alternatives to rational deterrence theory, the relationship between psychology and games of incomplete information, domestic institutions as a source of conflict, the evolution of cooperation on security issues, or the relationship between formal and empirical methods to the study of strategic interaction. Papers which make use of insights from other disciplines-e.g., psychology, sociology, anthropology, or economics-or historical comparisons would increase our understanding. This subject can be approached from an eclectic choice of methodologies: case studies, statistical, formal, normative. Proposals for complete panels will be especially welcome. Both paper and panel proposals should include an abstract.

Section 22. National Security. Stephen M. Walt, Department of Political Science, University of Chicago, 5828 S. University Avenue, Chicago, IL 60637; (312) 7028050.

A major problem in the field of national security studies is the need for effective evaluation. Accordingly, I encourage proposals that will perform a critical assessment of major national security issues; what policies have states adopted in the past and how well did they work? To the extent that errors were made, what caused them? Panels may address a wide variety of topics, including (but not confined to): arms control, U.S. or comparative grand strategy, the role of the military-industrial complex, the causes and effects of different military doctrines, and the measurement of military power. Both roundtables and more conventional formats are welcome.

Many of the most exciting recent developments in the field of national security studies have come from the marriage of history and social-science theory. Panels that address critical theoretical issues through the study of history and the use of comparative social-scientific techniques are strongly encouraged. In particular, I hope that this section will contribute to the growing sophistication of national security studies as a cumulative, socialscientific enterprise.

Section 23. International Political Economy. James A. Caporaso, Department of Political Science, DO-30, University of Washington, Seattle, WA 98195.

Panels of this section will attempt to reflect the theoretical and methodological diversity of the field. Papers and panel themes are invited for topics in Marxist international political economy, neoclassical approaches to international institutions, cooperative versus conflictual approaches, and mercantilist analyses of power and wealth. While the major debates in the field will tend to structure the panels one distinctive emphasis of this year's IPE panels will be on the importance of second-image factors (including societal forces and state policy) in the international systems.

Papers that bring to the fore current theoretical and methodological controversies are particularly welcome. Important contemporary topics, especially to the extent that they prompt theoretical debates, are also encouraged. Finally, development issues, to the extent that they are structured internationally, will appear on the program. 
Section 24. Foreign Policy Analysis. Jack Snyder, Institute for War and Peace Studies, 420 W. 118 Street, Columbia University, New York, NY 10027; (212) 8548290.

The subject matter of this section will be interpreted broadly. All approaches and methodologies are invited. Papers comparing the foreign policies of different states, or developing a conceptual framework for such comparisons, are especially encouraged. Also, the foreign policy consequences of the democratization of Communist or authoritarian regimes is a timely subject that panelists may wish to address.

\section{Section 25. Intersections of Theory and} Practice. Kim Lane Scheppele, University of Michigan, Institute for Public Policy Studies, 466 Lorch Hall, Ann Arbor, MI 48109; IPPS: (313) 764-7507; law school: (313) 747-1098; home: (313) 662-4695.

"Intersections of Theory and Practice" is a new section, a forum for interdisciplinary advances in theory to be brought to bear on the practice of research in political science. Many disciplines in the social sciences and humanities are witness to an explosion in theoretical thinking these days. Feminist theory, postmodernism, poststructuralism, deconstruction and an astonishing variety of new (and reconditioned) political, social, legal and literary theories are criticizing the behaviorist, positivist and foundationalist accounts that have comfortably resided in the discipline of political science. They are also providing new (or revived) models of scholarship. Traditional modes of scholarship within the discipline are changing to take into account advances in methodology and changes in the theoretical perspectives which are now available. In this section, we will take stock of the explosion of theories across the fields of human studies and assess their relevance for the study of politics.

I welcome individual papers as well as suggestions for panels and non-traditional sessions. Proponents and critics of all orientations are encouraged to submit ideas and to participate in the sessions. I hope to include not only political scientists but also members of other disciplines in the sessions. I would particularly like to ask members of other disciplines to consider how your fields might aid in the study of politics and suggest to members of the association that you invite colleagues in other fields to participate in the 1990 APSA meetings.

This call for papers and ideas is meant to leave open a great many questions. It is also meant to stimulate thinking about the ways in which we use theoretical orientations and insights in the empirical work of the discipline. I would particularly like to encourage suggestions that show how connections between theory and practice might be made rather than talk about how it might be done. Good examples are likely to teach more than calls to action. But I hope that this call for action will generate good examples of the uses of theory in empirical research.

\section{Organized Sections Program Panels}

Organizers for the APSA Organized Sections will describe their proposed programs below:

Section A. Political Methodology. Nathaniel Beck, Department of Political Science, University of California, San Diego, La Jolla, CA 92093: (619) 534-4296; and Gary King, Department of Government, Harvard University, Cambridge, MA 02138; (617) 495-2027.

Panels in this section will be of two types. The first will either apply new methods to existing political science problems or show the utility of existing methods in application to new political science problems; the second will assess the state of methodology in various substantive subfields and deal with more general epistemological issues.

While some of the papers in the first type of panels will report on analyzes of familiar methodological topics (measurement, estimation, inference, crosssections, panels, time series, selection bias, graphics, simulation, artificial intelligence, data collection, and survey research methods), we especially encourage papers that either design new methods to deal 
with interesting political science problems or use more standard methods in a new way to take advantage of the political features of a problem. Papers which tackle important substantive issues will be given priority. We also welcome papers that describe the state of the art in some welldefined methodological area (providing the link to important political science issues is made clear).

The second type of panel will deal with broader questions about the role of methodology in the various fields. Possible questions include: should there be a single political methodology? why do some fields of political science seem more methodologically advanced than others? how could we improve the relationship between political theory and empirical meth. odology? what is (or should be) the relationship between formal theory and empirical methodology? what are (or should be) the relationships between political methodology and the methodological fields in other disciplines? what methodological problems are distinctive to political science? how should the emerging field of political methodology be defined?

While most of the panels will deal with statistical methodology, panel and paper proposals on non-standard and/or nonquantitative methodology are also welcome.

Section B. Legislative Studies. Burdett Loomis, Department of Political Science, University of Kansas, Lawrence, KS 66045; (913) 864-3523.

What's wrong here? The Senate is judged almost impossible to lead, the House is regarded as simply impossible, and state legislatures chew up their leaders before (Connecticut, North Carolina) and even during (Oklahoma) their sessions.

Papers are solicited on all subjects relevant to the legislative process and to legislatures, and especially those that address problems of ethics, leadership, careerism, and campaign finance in contemporary legislative bodies. This call derives from experiences within the United States, but comparative analyses are more than welcome.
Section C. Presidency Research. Peri Arnold, Department of Government and In. ternational Studies, University of Notre Dame, Notre Dame, IN 46556; (219) 239. 7312.

The Presidency Research Group this year would like to emphasize approaches to the study of the presidency using concepts from the disciplines of psychology, sociology, anthropology, history, law and philosophy. The emphasis will be on the development of general theory, as well as attempts to explain the causes and consequences of idiosyncratic developments which shift the course of American politics. These approaches may be used to address the traditional topics addressed by presidential scholars such as the institutionalization of the presidency, the relationship of president to staff, his management of the media and relationship to the public, his political skills as manifest in the policy process and executive-congressional relations. Innovative panels dealing with the presidency through topics such as cognitive styles and the policy process, the sociological aspects of the use of power, etc. are especially welcome. Proposals for substantive as well as methodological panels and papers are encouraged.

Proposals for panels and individual papers should be submitted as soon as possible. Please include a short abstract describing your proposed panel or paper.

Section D. Political Parties and Organizations. James L. Gibson, Department of Political Science, University of Houston, itouston, TX 77204; office: (713) 7494322; home: (713) 660-8813; FAX: (713) 747-8638; BITNET: POLSBR@UHUPVMI.

I would like the 1990 Political Parties and Organizations panels to reflect a balance between conventional and innovative research. On the conventional side, papers dealing with party organizations, parties and electoral politics, parties and money, PACs and other interest groups, party elites, and such process concerns as linkage, integration, realignment, governance, etc., are certainly welcomed. I also especially encourage papers that might not ordinarily seem to fit within the traditional conception of political organizations and 
parties. For instance, papers that are cross-national in focus are encouraged, as are papers that combine a concern with political organizations and parties with other institutional and process concerns (e.g., interest group activity in the courts; the role of parties in the legislative process). Diachronic analyses are also especially encouraged. It should also be stressed that the section invites papers on political organizations other than political parties. Note that no methodological orthodoxy is being imposed on the papers-research based on eclectic methods, so long as they are rigorous, is welcomed. Formal analyses are especially encouraged. I also solicit your suggestions for additional topics for the meeting, and especially ideas for innovative roundtables. Finally, please make a special effort to encourage graduate students to consider participating in the meeting.

Section E. Law, Courts and Judicial Process. Stuart A. Scheingold, Department of Political Science DO-30, University of Washington, Seattle, WA 98195; (206) 543-2377 (Scheingold) or 543-6493 (McCann).

The objective of the 1990 panels of the Organized Section will be to pursue two forms of outreach. Most importantly, the idea will be outreach within the section. To this end, my Program Associate, Michael McCann, and I will particularly welcome proposals that draw on the variety of intellectual resources available among section members so as to diversify individual panels. Take, for example, a panel on a policy issue. Theory and jurisprudence can identify the policy's deeper structure; judicial process analysis can provide insight into the problems of legalizing policy issues; doctrinal analysis can explore the logical coherence and normative significance of authoritative decisions; law and society analysis can put legal process into its social, political, and economic contexts. As this last point suggests, it also makes sense to reach beyond the boundaries of the organized section to explore common ground with other portions of the discipline.

This proposal does not assume that each panel must stretch out in all the directions outlined above. Michael and I do, however, want to encourage as much outreach as is feasible. Our objective is to capitalize on the section's intellectual diversity to develop a mutually enriching internal colloquy as well as a meaningul exchange with other fields in the discipline.

Section F. Public Administration. Frank !. Thompson, Graduate School of Public Affairs, State University of New York at Albany, 135 Western Avenue, NY 12222.

The Organized Section on Public Administration welcomes proposals for papers as well as offers to chair or serve as a discus. sant on panels covering the full range of issues in public administration. There issues include, but are certainly not limited to: bureaucratic politics, organization theory, public management, budgeting, bureaucracy and implementation, the politics of personnel processes, administration in the states, intergovernmental administration, and privatization. Proposals which seek to foster theoretical insight into the politics of administration by proxy are especially welcome.

Detailed proposals for papers or panels will receive the strongest consideration. Prospective discussants should indicate their substantive areas of particular interest. Early submissions are encouraged.

Every effort will be made to coordinate the panels of this section with those being arranged by Professor Martha Derthick on behalf of the official program committee.

Section G. Federalism and Intergovernmental Relations. Ellis Katz, Center for the Study of Federalism, Temple University 025-25, Philadelphia, PA 19122; (215) 787-1482; and Robert Thomas, Department of Political Science, University of Houston, Houston, TX 77004; (7I3) 7494887.

To encompass the diverse elements for Federalism and Intergovernmental Relations for the 1990 Program, we invite panels, roundtables and workshops on a full range of topics. These topics may cover areas such as (1) the administrative and fiscal dimensions of federalism and intergovernmental relations, (2) theories of 
federalism, (3) comparative federalism, (4) constitutional aspects of federalism, (5) federalism and the political process, and (6) state politics and political culture.

Suggestions for sessions, papers and other forms of participation should be sent to Ellis Katz.

Section H. Urban Politics. Bryan D. Jones, Department of Political Science, Texas A\&M University, College Station, TX 77843; (409)845-8833; BITNET: H553BJ@ TAMVMI.

As always, the urban politics section is interested in dialogue between diverse viewpoints to understanding urban political phenomena.

The urban politics section welcomes panel and paper proposals on any of the diverse topics that urbanists have studied. The section particularly welcomes proposals that meld ideas or data developed in the field of urban politics with ideas or data from other parts of the disciplinecomparative politics, intergovernmental relations, public policy, and political economy, for example.

The section also would view positively creative proposals for diversifying the traditional paper presentation approach to program participation. Other disciplines, such as geography, use poster sections to present results from specific studies; this or other modes of presentation could be explored.

Section I. State Politics and Policy. Virginia Gray, Department of Political Science, 1414 Social Science Bldg., University of Minnesota, Minneapolis, MN 55455; (612) 624-4I44.

The newly organized section on state politics and policy welcomes proposals on any aspect of state government and politics, including institutions, organizations, and policies. We are particularly interested in papers that seek to advance the theoretical development of the field. Also we expect to offer a few panels focused on key substantive issues facing states, e.g., economic growth and performance, abortion reform, etc. Proposals for individual papers or suggestions for panels are equally appropriate.
Section J. Policy Studies. B. Guy Peters. Department of Political Science, University of Pittsburgh, Forbes Quad. 4T20, Pittsburgh, PA 15260; (4I2) 648-7285.

The study of public policy in political science has made substantial theoretical and analytical progress, but remains in need of even greater progress in these areas. We have good descriptive information on specific policy areas, and on some stages of the policy process, but often have not integrated this information into broader frameworks. Therefore, although there will still be a place for some panels concerned with the politics of specific policy areas, the desired emphasis in this set of panels will be on extending broader analytic and theoretical themes. Some of these themes are persistent ones, but the problems which they raise have yet to be "solved" to the satisfaction of most scholars in the field. Some specific topics which might be the subject of panels and/or papers include:

a). Analytic models of the policy process and the linkage of process characteristics to policy outcomes:

b). The dynamics of change in public policy;

c). The design of public policies, especially the linkage of the political sys. tem and technical experts;

d). The role of advice and systems of advice in the formulation of policy (this may include the concepts of "policy communities" and "networks");

e). The role of comparative analysis in theory formation, including comparison among policy areas as well as comparison among political systems.

The above list is not exhaustive, but it does give some idea of the range and type of issues which will be of particular interest and concern in developing this set of panels.

Section K. Women and Politics Research. Pamela Johnston Conover, Department of 
Political Science, Hamilton Hill 070a, University of North Carolina at Chapel Hill, Chapel Hill, NC 27599-3265.

This section will be defined broadly in order to encompass the full range of topics that fall within the scope of women and politics. Paper and panel proposals are welcome that deal with any aspect of women and politics research including the political behavior of women, women and public policy, women and political institutions, feminist theory, and generally topics relating to the theory, concepts, and methods concerned with the study of women and politics. Proposals dealing with women in a comparative perspective, those dealing with minority women, and those uniting political theory and empirical research are especially welcome.

Section L. Comparative Politics. John R. Freeman, Department of Political Science, University of Minnesota, 1414 Social Science Bldg., Minneapolis, MN 55455; (612) $624-4144$ or $624-6018$.

For the 1990 Annual Meeting, the Organized Section in Comparative Politics expects to organize a full set of panels. While detailed discussion of the plans and programs of the section will take place at the first organizational meeting of the section members which will be held at the 1989 Annual Meeting (Friday, September I; 5:30 P.M.), the following provides a general indication of what we are seeking.

There has been much new and exciting work in the field of comparative politics in recent years, work which spans areas, narrowly defined subdisciplinary fields and methodological boundaries. In addition, the last decade has witnessed a growing interdependence between the United States and other nations of the world. The panels of the section are expected to promote the comparative, and especially cross-national, study of politics. Panel proposals should strive to propose topics which span areas (including the U.S) and/or papers which are cross-national. Panels which explore a specific theoretical theme about which there is ongoing debate and which lends itself to cross-area study and/ or to the use of different methodological approaches are also welcomed. What we are hoping to have is a section of panels which contribute to a reduction of the fragmentation-into areas, highly specialized substantive subfields or narrow methodological or theoretical specializations - of the comparative fields or which at least prompt discussion of the differences within the field and their merits and limitations.

\section{Section M. Politics and Society in Western} Europe. George Ross, Sociology Department, Brandeis University, Waltham, MA 02254; (617) 736-2636.

The purpose of the section is to promote comparative discussion, research and debate about the changing sociology of politics, the state and social structures in modern Western Europe.

Section N. International Security and Arms Control. Paul R. Viotti, P.O. Box 138, U.S. Air Force Academy, CO 80840; (719) $472-2270$.

The section seeks papers on national and international security and arms control topics. We weicome all proposals regardless of methodological approach or normative perspective.

\section{Section O. Foundations of Political} Theory. Robert Grafstein, Department of Political Science, Baldwin Hall, University of Georgia, Athens, GA 30602; (404) 542-2057.

As noted in its APSA summary description, the Foundations section "is committed to the linkage of political theory and philosophy with political science as a disci. pline, with the consequences of development, in successful cases, of cross-fertilization and stimulation." Paper and panel proposals reflecting this commitment, broadly construed, are particularly welcome. Membership in the formal section is by no means required and all proposals anchored in empirically or normatively oriented political theory or philosophy will receive careful consideration. Joint sponsorship of panels from other sections is possible when appropriate. 
Section P. Representation and Electoral Systems. Joseph F. Zimmerman. Graduate School of Public Affairs, State University of New York at Albany, 135 Western Avenue, Albany, NY 12222; (518) 442-5378 or (518) 439-9440.

The Section is interested in receiving panel proposals for the 1990 meeting on the topics of Theories of Representation, the Twenty-Fifth Anniversary of the Voting Rights Act of 1965, the Impact of Electoral Systems upon Minorities and Women, Run-Off Elections, Election Administration, Electoral Participation, the Initiative and the Referendum, the Recall, Legislative Redistricting witr, Emphasis upon Gerrymandering, Alternative Electoral Systems (Cumulative Voting, Limited Voting, Preferential Voting, Proportional Representation), and Foreign Experience with Electoral Systems.

The above topics are suggestions and the Section welcomes the suggestion of other topics. The Section has a particular interest in proposals for panels on topics that have been neglected in the literature.

Section Q. Conflict Processes. Randolph Siverson and Robert Jackman, Depart. ment of Political Science, University of California at Davis, Davis, CA 95616; (916) 752-3078 (Siverson), (916) 752-0966 (Jackman).

Proposals that deal with all forms of political conflict, treat this subject with some rigor or apply an interdisciplinary perspective are invited. Papers can deal either theoretically or empirically with the problem of war and peace broadly defined to include the analysis of the initiation, escalation, deterrence or resolution of domestic and international conflict as well as the management of disputes, crisis and confrontations.

Acknowledging that work in this field is very diverse our roundtables and panels will aim to represent all facets of innovative work dealing with conflict. All approaches to this topic-including empirical, formal or normative-are equally encouraged. Papers may focus on the work of a major scholar or school, or on topics such as deterrence, war, trade, governmental stability, racial strife, strikes, demonstra- tions or terrorism. Emphasis on conflict resolution and management are particularly encouraged.

Inquiries should include a reasonably descriptive abstract of the proposed panel, roundtable or paper not to exceed three pages. Early submission of proposals is strongly encouraged.

Section R. Politics and the Life Sciences. Joseph Losco, Department of Political Science, Ball State University, Muncie, IN 47306; (317) 285-8780.

The life sciences encompass a broad spectrum of theoretical, empirical, and policy approaches contributing to the study of traditional philosophic positions concerning, for example, human nature; epistemological matters concerning the structure of explanation across natural and social science disciplines; reassessment of the social and biological construction of gender; and consideration of the concepts of genetic and cultural evolution. Empirical studies include the study of somatic and psysiological variables affecting the behavior of elites and masses; the naturalistic study of elite behavior, verbal and nonverbal; and the ecological impact of particular types of human behavior. Policy interests range from the effect of aging populations on the political agenda, to traditional health care issues, to the social and political impacts of genetic and biomedical technology on human reproduction and the environment.

In the interest of stimulating broader interest of these issues within political science, panel and paper topics are encouraged which address fundamental concepts and themes in traditional or behavioral political science in light of contemporary research and theory from the life sciences. Panels which show promise in being cosponsored with other organized sections are particularly welcomed. Examples include, but are not limited to, the exploration of the relationship between reproductive technologies and the social control of women; environmental politics, for example, the debate over ozone depletion; and the use of evolutionary theory in assessing traditional concepts in political philosophy. Suggestions for roundtables 
are workshops are encouraged; however, those with ideas for complete panels are encouraged to submit ideas early to allow time for panel development. Those who wish to serve as panel chairs or discussants should indicate their preferred areas and topics of interest.

Section S. Religion and Politics. Lyman A. Kellstedt, Department of Political Science, Wheaton College, Wheaton, IL 60187; (312) 260-5129.

The religion and politics program should reflect the great diversity of research topics and methods in this field. I welcome proposals reporting empirical research on religion and politics in the United States, the developed nations, and the third world, as well as normative and historical research on religion and politics, the Bible and politics, church and state, and political theology. I encourage proposals reporting local, nationak, and cross-national research. Proposals based on recently or soon to be completed dissertations are particularly encouraged.

In particular, I would invite paper proposals that focus on the role of religion in the 1988 election in the United States. Other possible topics for panels include assessing the political impact of the local congregation versus the denomination, versus the attitudes of individual believers as well as the mobilizing effects of pastors, peers, interest groups, and/or religious television. Assessments of establishment and free exercise clause jurisprudence are also in order. In addition, paper proposals are encouraged that assess the political impact of the Christian base community movement in various Latin American countries as well as Liberation Theology itself.

The religion and politics section of the APSA has always attempted to mix types of panels; therefore, you are invited to submit proposals for roundtables and for panels focusing on one major work in the field, as well as the traditional panels featuring three or four papers with discussants. Detailed proposals and early submissions are encouraged.

Section T. Applied Political Science. Howard J. Silver, Consortium of Social
Science Associations, 1522 K Street, NW, Suite 836, Washington, DC 20005; (202) 842-3525.

Panels in this section should focus on how our political science training is applied in government at all levels, the non-profit sector including academia, and the forprofit sector. Interpret "applied political science" as broadly as you desire. Training of political scientists in the application of their knowledge can also be a focus. Applying political science in conjunction with other social and non-social sciences can also be the subject of panel proposals. Panels that used to be in the "political science as a profession" section would be welcome here.

Section $U$. Science and Technology Studies. Norman J. Vig, Department of Political Science, Carleton College, Northfield, MN 55057.

The STS Section encourages new thinking and research on all aspects of the relationships between science, technology and politics. Most of the APSA panels and papers thus far have been concentrated in the following three areas, but work related to all fields of political science is encouraged:

1. Policy analysis and decision making, including institutional studies, case studies, and generic process studies (e.g., risk assessment, technology assessment);

2. Political theory, including the problem of technocracy, the consequences of new technologies for constitutional law and democratic processes (e.g., elections), and the broader relationship between technological artifacts and political values;

3. Comparative science and technology studies, including national science policies, comparative strategies for promotion and control of specific technologies, and crossnational technology transfer and its relationship to development.

Section V. Computer Users. Michael L. Vasu, Department of Political Science and Public Administration, North Carolina State University, Raleigh, NC 27695-8102; (919) 737-2481. 
The Computer Users section of the American Political Science Association is issuing a call for papers and panels for the 1990 Annual Meeting in San Francisco. The general areas around which we would like to organize panels are as follows: social science research computing; instructional software and hardware computing in the classroom; and computers and politics. Please submit an abstract of either the paper or the proposed panel to Michael $L$. Vasu.
New! Section W. Political Communication. Doris Graber, Department of Political Science, University of Illinois at Chicago, Box 4348, Chicago, IL 60680; (312) 990-3105.

The purpose of this section is to foster the study of political communication. The section seeks to provide a forum for research on the mass media and their effects on the public, political institutions and processes, telecommunications policy, and impact in new media technologies, as well as research on the process of communicating and understanding about politics.

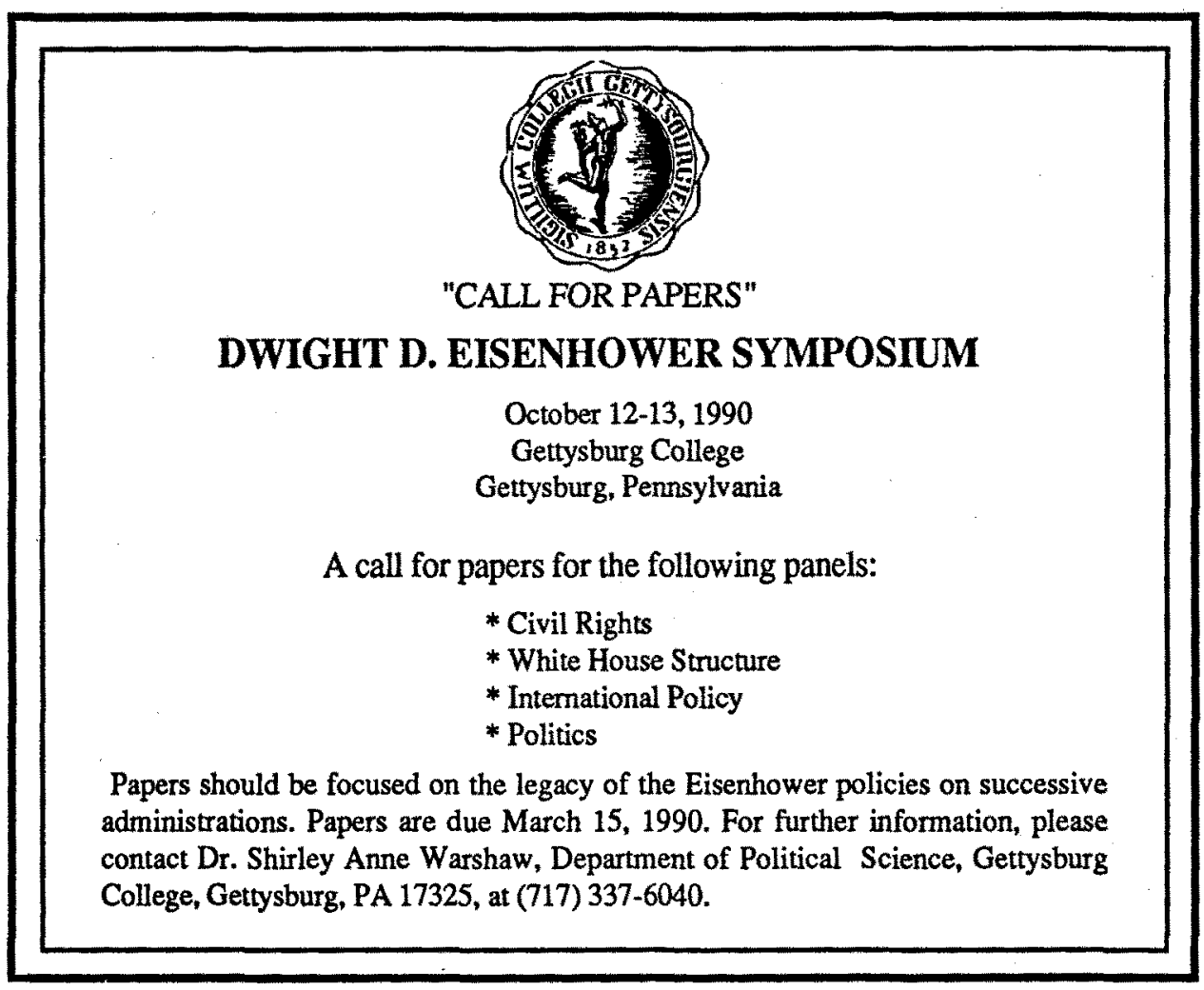

